\title{
Practice and Research on the Collaborative Education Model of Applied Undergraduate Cross-border E-commerce
}

\author{
Taking Guangdong University of Science and Technology as an Example
}

\author{
Ni Wang \\ Institute of Finance and Economics \\ Guangdong University of Science and Technology \\ 523083 Dongguan, Guangdong, China \\ E-mail: 280605694@qq.com
}

\author{
Ming Luo \\ Institute of Finance and Economics \\ Guangdong University of Science and Technology \\ 523083 Dongguan, Guangdong, China \\ E-mail:luoming8654@163.com
}

\begin{abstract}
With the rapid development of cross-border electronic commerce, it is challenging to train foreign trade talents for applied undergraduate course. In the process of training talents, Guangdong Institute of Science and Technology is facing with the challenges, such as lack of practical platform and lag of knowledge updating and so on. It Relies on the school industry and school enterprises to build a collaborative education mode, to cultivate cross-border e-commerce talents, which conducts useful practice and exploration in aspects of reforming related courses of cross-border electronic commerce in the teaching and training cross-border e-commerce teachers with the help of industry associations.
\end{abstract}

Keywords: Applied undergraduate course; Collaborative education; Model; Practice

\section{INTRODUCTION}

With the vigorous development of cross-border ecommerce, cross-border e-commerce talents are being paid more and more attention. In 2017, the total transaction scale of cross-border e-commerce in China (including retail and B2B) reached 7.6 trillion yuan, of which the total retail import and export volume of Customs cross-border ecommerce management platform reached 90.24 billion yuan, up $80.6 \%$ over the same period last year. The new form of cross-border e-commerce poses an unprecedented challenge to training of foreign trade talents by the applied undergraduate course. Cross-border e-commerce is a kind of international commercial activity, that the transaction subjects belonging to different customs through e-commerce platforms to achieve transactions, payment and settlement, and through cross-border logistics to deliver goods and complete the transaction. Cross-border e-commerce talents need to have the knowledge and skills of e-commerce, network marketing, international trade and foreign language and so on. Generally speaking, the talent training system in colleges and universities is only a unilateral training of a certain professional talent, not taking into account the comprehensive training of talents adapted to the new trade and new forms of business, and because of the lack of teachers with practical experience in cross-border e-commerce, the knowledge of students learned is often out of touch with the actual operation of the enterprise, so it can not meet the needs of the new era enterprises for the cross-border e-commerce talent. This article takes the cooperation of industry association, talents training base of Dhgate cross-border e-commerce and the university to train the cross-border e-commerce talents as an example, explores and analyzes the new mode of collaborative education to train cross-border e-commerce talents.

\section{CHALlENGES FACED BY CROSS-BORDER E-COMMERCE TALENTS TRAINING}

\section{A. Lack of Practical Platform}

The cultivation of cross-border e-commerce talents must keep up with the industry, enterprises and markets, having a high level of skills. But in the training process of current applied undergraduate cross-border e-commerce talents, on the one hand, the construction of its own practice platform lags behind, while on the other hand, the school-enterprise cooperation training platform is not perfect, which cause that the training still stays in the instillation of textbook theory and less practical skills closed to the industry and enterprises in the teaching course.

\section{B. Lag of Knowledge Renewal}

Cross-border electronic commerce is the product of knowledge economy, which changes quickly and presents new knowledge, new technology and new mode. This requires our teachers to keep up with the pace of the times, and continue to practice, constantly charged, constantly updated, only in this way to make their knowledge structure to be supplemented, updated. However, in addition to the heavy teaching tasks, it is difficult for the applied undergraduate teachers to take out time to improve their practical learning, the phenomenon of knowledge aging is common, and it is difficult to follow the rapid changes of cross-border e-commerce industry.

\section{A Serious Shortage of Teachers}

Due to the fact that cross-border electronic commerce is a new interdisciplinary subject, talent training is still in its infancy. Especially the serious lag in the training of high-level 
cross-border e-commerce professionals above graduate level in turn aggravates the supply needs of applied undergraduate cross-border e-commerce teachers. In addition, the nature of cross-border e-commerce professional let it formed the limitations of cross-border e-commerce teachers, changing more, less academic background, so the teachers have poor cross-border e-commerce systematic knowledge.

\section{THE IDEA AND PRACTICE OF CROSS-BORDER E- COMMERCE COLLABORATIVE EDUCATION MODEL}

\section{A. "University, Industry Association and Enterprise" Cultivate Cross-border E-commerce Talents Together}

The training base of cross-border e-commerce talents aims at the characteristics of the industry and region of the enterprise, training students to learn the operation of multicross-border platforms specially, such as B2B and B2C, etc., to achieve zero-distance employment of students. Under the guidance of industry associations, colleges and Dhgate jointly set up a training base for cross-border e-commerce talents, aiming at the frontier trends and development trends of the Internet and e-commerce, and taking the demand of cross-border e-commerce enterprises as the guide, to jointly train the cross-border e-commerce businessmen who know the cross-border e-commerce knowledge and have the operational skills and practical experience.

Cooperation the model of collaborative training crossborder e-commerce talents by school, industry and enterprise is to based on school-enterprise collaborative talent training model, plus industry associations to strengthen the coordination and communication between enterprises. The industry association sets up communication channels and information publishing platform for universities, employers and talent training institutions. Formulate the standards and specifications of training and using of talents, and to carry out the level certification of talents. Set up industry entry and exit threshold, calculate and provide relevant information, monitor and forecast industry development. Maintain trade order and promote the healthy development of the industry.

As a middleman of cooperation between schools and enterprises, industry associations participate in the training of cross-border e-commerce talents by coordinating the relationship between universities and enterprises, setting up a talent training platform, organizing online education and offline training, professional competence competitions and certification, teacher training, etc. At least the following five objectives can be achieved. The first is to realize the connection between the construction of professional curriculum and the development of cross-border e-commerce industry. The second is to realize the connection between the content of the relevant curriculum module of cross-border ecommerce and the corresponding post business content. The third is to realize the connection between the professional teaching process and the enterprise operation process. The fourth is to realize the connection between the professional competence certificate of students and the ability requirements of the enterprise posts. The fifth is to realize the sharing of teaching resources such as university teaching resources, practical training software and hardware, practice teaching base and so on.

\section{B. Related Courses of Reforming Cross-boundary E- commerce}

The training standards of cross-border e-commerce talents are built by the cooperation of university, industry and enterprises and set up the relevant cross-border ecommerce curriculum system according to the practical skills needs of industry and enterprise.

\section{1) Reform the curriculum system}

The introduction of Dhgate training course system enables students to understand the basic functions of Dhgate international website and Aliexpress platform and master the platform operation skills of the platform, so as to have the marketing thought of cross-border e-commerce and the ability of platform promotion and optimization. The basic knowledge of cross-border e-commerce is taught by school teachers, and the practical operation and running of Dhgatenet platform are taught by enterprise mentors. Basic knowledge of cross-border e-commerce include: analysis of the current situation and development trend of cross-border e-commerce, analysis of cross-border e-commerce talents, understanding of cross-border e-commerce Dhgate platform, management of cross-border e-commerce, details of setting up shop on Dhgate and Aliexpress platforms and how to locate industry products, products introduction of Dhgate platform, picture beautification and PS software application and so on. The practical operation and running knowledge of Dhgate platform: analysis of platform basic situation, analysis of platform industry, analysis of enterprise basic situation, practical operation of setting shop on Dhgate platform, analysis of main charts and detail page, pictures and custom attributes, PS actual operation of pictures, edition contents of details page, the definition and classification of keywords, analysis of hot words competitiveness power, category, keyword and product name, hot searching words and keywords list, releasing products in international website, practical operation of product releasing, Dhgate platform and its data, Dhgate platform data and ranking, etc.

\section{2) Setting up practical course system}

On the basis of training courses, it should fully integrate the enterprise resources of cross-border e-commerce industry, and attract enterprises to enter the university. The services, such as website building, platform promotion, receiving orders, documentary delivery and data analysis and so on, are provided for the cross-border e-commerce enterprises. Practical experts in cross-border e-commerce enterprises teach students the latest practical skills. Establishing the website practical training, like shop decoration and product releasing, etc., promotion practical training, like setting up key words, SEO and overseas promotion, etc., order receiving practical training, like product pricing and quotation, inquiry processing, communication with 
customers, etc., consignment practical training, like contract signing, cargo transportation, customs declaration and inspection, etc., data analysis practical training, like buyers distribution and products heating analysis etc. So that students can help enterprises to operate cross-border electricity business practically in school.

3) Training cross-border e-commerce teachers with the help of industry association

Cross-border e-commerce knowledge updates quickly, and then new technologies and new theories continue to emerge. And these frontier new knowledge, new technology and new theory of cross-border e-commerce are firstly created, practised and produced by well-known cross-border e-commerce enterprises. Therefore, we should strengthen exchanges and cooperation with front-line cross-border ecommerce enterprises, train teachers of cross-border ecommerce with the help of trade associations, so as to enable cross-border e-commerce teachers to integrate with the new frontier theory of cross-border e-commerce in the world, master the current advanced cross-border e-commerce technology and improve cross-border e-commerce skills and scientific research capabilities, which is also a shortcut of training cross-border e-commerce teachers in applied undergraduate colleges and universities.

On the basis of strengthening the exercising of crossborder e-commerce platform, the colleges seek the enterprise cooperation actively. One is send cultivation. Seven teachers have been selected and send to the China Foreign Trade and Economic Cooperation Enterprise Association to carry out training, including cross-border e-commerce industry development and business model, cross-border e-commerce (Dhgate and Aliexpress) platforms operational training, cross-border SNS marketing and logistics operation, construction of cross-border e-commerce curriculum system and curriculum resources development, cross-border ebusiness training teaching and practical training project development. In cooperation with Dhgate and Guangdong Baida Electronic Commerce Co., Ltd, 5 teachers have been selected to participate in the cross-border e-commerce practice. Through the training of first-line cross-border ecommerce enterprises, cross-border e-commerce teachers can keep up with the frontier of cross-border e-commerce, grasp the frontier technology and skills of cross-border ecommerce, which greatly shorten the teacher training cycle. The second is to operation cultivating in cooperative enterprises. To seek deep cooperation with the enterprise and explore the thirdpartnar operation of the enterprise online store actively. In cooperation with Shenzhen Qianhai Youchuang Electronic Commerce Company and Dongguan Tianzhi Technology Co., Ltd., teachers and students form teams together to participate in the enterprise operation, in which teachers act as managers of cross-border e-commerce department and technical department and students operate the enterprise stores as thirdpartnar directly under the guidance of teachers.
4) To promote learning by competition, to promote research by competition and to promote teaching by competition

It should give full play to the leading role of vocational skills competition to promote the growth of teachers' teaching ability. On the one hand, vocational skills competition is the competition of students' ability and quality, but on the other hand, it is the measure of teachers' teaching level and skill level. In the process of the skill contest, the teachers' professional ability, teaching level and skill level will be greatly improved through the training guidance of theory and skills, learning, communication and cooperation with enterprises and peers. For the majority of teachers and students, in the embodiment of "to promote education by competition" at the same time, it also reflects "to promote learning by competition, to promote growth by competition."

In the training of cross-border e-commerce talents, the college explicitly proposes to take "skill contest as the starting point, to enhance teachers' and students' practical skills comprehensively", and to hold regular cross-boundary ecommerce skills competitions and web design competitions at the college level, etc. It will seriously select excellent students to form team to participate in all kinds of provincial and national skill contests and competitions, thus forming a good atmosphere of "to promote learning by competition, to promote research by competition and to promote teaching by competition", and bringing up high skilled talents. In 2017, the first prize was one, and the third prize was two in the National Cross-Border Electronic Commerce Entrepreneurship Competition. It exercises the organizational ability, logical thinking ability, business marketing ability, communication ability, decision-making and execution ability and team cooperation ability of the vast number of teachers and students in effect. Then teachers' professional ability and professional level have a rapid improvement, and teaching quality is also improved significantly.

To sum up, training cross-border e-commerce talents, "university, industry association and enterprise" collaborative education fully respects the market and integrates resources. Using mechanism actively, innovating management. Promoting the integration of industry and education, and realize the integration and innovation of the cooperation between the university, industry association and enterprise and the talents cultivation.

\section{ACKNOWLEDGMENT}

Fund: 2015 Higher education innovation strong school project in Guangdong University of Science and Technology [2016] 18 (2)

\section{REFERENCES}

[1] Jie Liu. Research on Construction of Collaborative Innovation System for Realization of More Attractive Higher Vocational Education[P]. 3rd International Conference on Arts, Design and Contemporary Education (ICADCE 2017), 2017.

[2] Xun Liu. The Impact of Cross-Border E-Commerce on the Problems of Chinese Economy New Norms [P]. 2017 International Conference 
on Innovations in Economic Management and Social Science (IEMSS 2017), 2017.

[3] Fei Wang. Study on E-commerce Development Strategies of Crossborder International Trade in China [P]. 2017 International Conference on Humanities Science, Management and Education Technology (HSMET 2017), 2017.
[4] Xiaojun Lu,Simeng Zhang. Analysis on the Strategy of Cross-border E-commerce Talents-Based on the analysis of policy content[P]. 2017 International Conference on Management Science and Management Innovation (MSMI 2017), 2017. 